\title{
NEW PERSPECTIVE ON RISE OF TUBERCULOSIS CASES: COMMUNAL LIVING
}

\author{
Şerif Kurtuluş ${ }^{1}$, Remziye Can², Zafer Hasan Ali Sak ${ }^{1}$ \\ 'Department of Chest Diseases, Faculty of Medicine, Harran University, Şanliurfa, Turkey \\ ${ }^{2}$ Mustafa Kemal Atatürk Vocational and Technical Anatolian High School, Eskişehir, Turkey
}

\section{SUMMARY}

Objective: Forced migration caused by wars has led to regression in health parameters, including tuberculosis. This study aims to determine the relationship between living area, family type and the number of contacts among refugees and Turkish citizens diagnosed with tuberculosis.

Method: This study was designed using retrospective file scanning. A total of 194 patients with diagnosed TB were included in this study. In addition, patients' addresses were visited and their family lifestyles and living areas were recorded.

Results: Of 194 patients in the age range of $1-72$ years (mean $=31.15, S D=15.16$ ), 98 patients were refugees. The number of contacts among refugees was 549 , and their total living area was $7,740 \mathrm{~m}^{2}$. A total of 57 refugees lived in a communal living situation, and their average living area was significantly lower than that of Turkish citizens. Statistical significance was observed between family lifestyle and habitats. This was found due to the difference between nuclear families and communal living situations.

Conclusion: Tuberculosis was found to infect more people in war-related living conditions. This situation is caused by communal living, which refers to people who are not blood relatives living together; this is new information. Communal life should be taken into account in the contact examination of refugees for tuberculosis, and the obstacles to reach health services for refugees living outside of camps should be examined.

Key words: communal living, contact, refugee, tuberculosis, war

Address for correspondence: Şerif Kurtuluş, Harran University Faculty of Medicine, Department of Chest Diseases, Şanliurfa, Turkey. E-mail: drkurtulus1@gmail.com

https://doi.org/10.21101/cejph.a6016

\section{INTRODUCTION}

Tuberculosis is an important public health problem both in Turkey and throughout the world (1). Wars, which lead to hunger, poverty, homelessness, and refuge, are another public health problem that facilitate the spread of diseases like tuberculosis causing them to be exhibited at a more severe rate (1-4). Contamination is an important factor that causes an increase in tuberculosis cases and living in the same area accelerates this phenomenon (1). The term "refugee", which was first described by the United Nations General Assembly in 1951 in Geneva (5), has also been associated with infectious diseases such as tuberculosis.

Family structure has been remodelled through history to meet communal needs. The communal living style in which both bloodrelated and non-blood-related people live together was determined by the first social structure seen in hunters and gatherers, which was later shaped by production, as well. Men hunting and women attending gathering activities shaped the communal structure, which was much like a tribe (6).

A nuclear family is the smallest family unit that includes two generations - one consisting of parents and the other of unmarried children - characterised by blood relation. The nuclear family provides a basis for the extended family $(7,8)$, which is a type of family in which a combination consisting of a leader, the leader's spouse, their children, the children's spouses, and grandchildren may live together in one household (8).
Tuberculosis formed by the Mycobacterium tuberculosis complex bacillus spreads through the air from infected patients to healthy persons $(1,3,4,9,10)$. Most infected patients exhibit pulmonary with cavitation and laryngeal tuberculosis. Smearnegative tuberculosis patients are less at risk of transmitting the disease $(1,11)$. To keep tuberculosis under control, infectious cases should be identified and treated in the shortest possible time by screening contacted people and administering prophylactic treatment (1). Infection of tuberculosis, also known as latent tuberculosis infection (LTBI), is diagnosed by the Mantoux tuberculin skin test (TST) or the interferon-gamma release assay (IGRA) (1), and chemoprophylaxis is a frequent preventive medication treatment $(1,12)$.

Contact examination is done to persons living in the same house with a tuberculosis patient. In addition, out-of-home individuals with whom the patients share the same environment should be examined. If a tuberculosis patient is detected in a communal living area (prison, barrack, dormitory, etc.), the other people sharing the same room are also considered to be contacts. Contact examination is extended in accordance with the bacteriologic outcome of the patient (1). If needed, preventive treatment is given for an adequate amount of time to hinder the development of the tuberculosis disease (1). Preventive treatment applications are done well in Turkey, as individuals receiving preventive treatment for tuberculosis were shown to result in a country-wide disease prevention rate of $60 \%(2)$. 
Protective treatments have been shown to have an efficiency of up to 19 years (9). These treatments have been shown to also be efficient in immunosuppressed patients (13). The first choice for chemoprophylaxis is isoniazid for a period of six months, with nine months being suggested for immunosuppressed patients (1).

The present study intends to analyse the relationship among contact numbers, family living style, and living areas in Turkish citizens and refugees who were diagnosed with tuberculosis.

\section{MATERIALS AND METHODS}

This study was conducted with 194 patients who applied to Harran University and were diagnosed with tuberculosis between 2012-2019. The number of contacts was taken from the patients' files. The participants' family living type and the size of their living areas in $\mathrm{m}^{2}$ were recorded by visiting their homes. Nuclear family was defined as a family type consisting of mother, father, and children, and extended family was defined as a family unit consisting of blood-related individuals aside from the nuclear family. Communal living was defined as the style in which nonblood-related people live together. The number of contacted people in the living area of tuberculosis patients was recorded, but the number of contact people in the working area was ignored. Using IBM SPSS Statistics for Windows, version 23 program, the frequency and the distribution were determined. The difference between family living type and number of contacted people was compared using the one-way ANOVA; the distributions in accordance with living area and number of contacts were compared using the Spearman's correlation analysis; and the difference between nationality and living area was compared using the t-test.

The study was approved by the Harran University Ethical Committee (9 September 2019, Session 10, Decision no. 26)

\section{Research Limitations}

Our study consists of tuberculosis patients and their indoor living contacts; contacts in the workplace environment were ignored. Only tuberculosis patients who were admitted to Harran University between 2012-2019 were included in this study, which could be accepted as a limitation. However, as only one reference health centre was located in this area, most tuberculosis patients were examined with the exception of individuals who did not choose to participate in the study.

\section{RESULTS}

Of 194 patients in the age range of $1-72$ years (mean $=31.15$, $\mathrm{SD}=15.16), 98$ patients were refugees. The study group consisted of 104 females $(53.6 \%)$ and 90 males $(46.4 \%)$ males. It was found that $98(50.5 \%)$ of the participants were refugees, where 72 $(37.1 \%)$ lived in a nuclear family (Table 1 ). Regarding the refugee population, the number of contacted people with tuberculosis was 549 , the size of the total living area was $7,740 \mathrm{~m}^{2}$ and the average living area for one refugee was $14.09 \mathrm{~m}^{2}$. For the group of Turkish citizens, a total of 487 were contacted persons with tuberculosis, the size of their living area was $11,370 \mathrm{~m}^{2}$ and the average living area for one person was $23.34 \mathrm{~m}^{2}$.

Lifestyles in accordance with nationality were analysed. A total of $57(58.2 \%)$ of the refugees had a communal living situation, and $47(49.0 \%)$ of the Turkish citizens lived with their nuclear families (Table 2).

Table 1. Study group's characteristics $(N=194)$

\begin{tabular}{|l|l|l|}
\hline & $\mathbf{n}$ & $\%$ \\
\hline \multicolumn{2}{|l|}{ Type of nationality } \\
\hline Refugee & 98 & 50.5 \\
\hline Turkish citizen & 96 & 49.5 \\
\hline Type of family \\
\hline Nuclear family & 72 & 37.1 \\
\hline Extended family & 62 & 32.0 \\
\hline Communal living & 60 & 30.9 \\
\hline
\end{tabular}

Table 2. Lifestyle according to type of nationality $(N=194)$

\begin{tabular}{|c|c|c|c|}
\hline & & $\mathrm{n}$ & $\%$ \\
\hline Type of nationality & \multicolumn{3}{|l|}{ Refugee } \\
\hline \multirow{3}{*}{ Lifestyle } & Nuclear family & 25 & 25.5 \\
\hline & Extended family & 16 & 16.3 \\
\hline & Communal living & 57 & 58.2 \\
\hline Type of nationality & \multicolumn{3}{|l|}{ Turkish citizen } \\
\hline \multirow{3}{*}{ Lifestyle } & Nuclear family & 47 & 49.0 \\
\hline & Extended family & 46 & 47.9 \\
\hline & Communal living & 3 & 3.1 \\
\hline
\end{tabular}

Table 3. Lifestyle, living area and count of contacts comparison

\begin{tabular}{|c|c|c|c|c|}
\hline & Mean & SD & F/p-value & Comparison of groups \\
\hline Type of family & \multicolumn{4}{|l|}{ Living area $\left(\mathrm{m}^{2}\right)$} \\
\hline Nuclear family & 89.02 & 56.36 & \multirow{3}{*}{$3.297 / 0.039$} & \multirow{3}{*}{$\mathrm{C}>\mathrm{N}^{*}$} \\
\hline Extended family & 98.06 & 47.50 & & \\
\hline Communal living & 110.33 & 33.84 & & \\
\hline Number of total contacts & \multicolumn{4}{|l|}{ Count (n) } \\
\hline Nuclear family & 4.97 & 1.66 & \multirow{3}{*}{$6.134 / 0.003$} & \multirow{3}{*}{$C>N>E^{*}$} \\
\hline Extended family & 5.11 & 1.95 & & \\
\hline Communal living & 6.02 & 1.83 & & \\
\hline
\end{tabular}

${ }^{*} \mathrm{C}$ - communal living; $\mathrm{N}$ - nuclear family; $\mathrm{E}$ - extended family 
Table 4. Average living area comparison according to type of nationality $(N=194)$

\begin{tabular}{|l|c|c|c|c|c|}
\hline \multirow{2}{*}{$\begin{array}{l}\text { Type } \\
\text { of nationality }\end{array}$} & \multirow{n}{*}{$\mathbf{n}$} & \multicolumn{2}{|c|}{$\begin{array}{c}\text { Living area } \\
\left(\mathbf{m}^{2}\right)\end{array}$} & \multirow{2}{*}{$\mathbf{T}$} & \multirow{2}{*}{ p-value } \\
\cline { 3 - 4 } & & Mean & SD & & \\
\hline Refugee & 98 & 78.97 & 51.08 & \multirow{2}{*}{-6.281} & $<0.001$ \\
\hline Turkish citizen & 96 & 118.43 & 35.10 & & \\
\hline
\end{tabular}

Participants with a nuclear family lived in an area of $89.02 \pm 56.36 \mathrm{~m}^{2}$, extended families lived in $98.06 \pm 47.50 \mathrm{~m}^{2}$, and people with a communal living situation lived in $110.33 \pm 33.84$ $\mathrm{m}^{2}$. In the analyses of living area in accordance with family type, the differences between the nuclear family group and communal living group were statistically significant $(p<0.001)$ (Table 3$)$.

According to our findings, people who live in a nuclear family type had an average of four contacts, those who lived in an extended family had five and participants with communal family living situation had an average of six contacts. The correlation between the total number of contacts and the determined family type among the different groups was statistically significant. This statistical significance was caused by the differences between the nuclear family and extended family groups $(\mathrm{p}<0.001)$ (Table 3$)$.

In Table 4, the average living area was examined in accordance with nationality types. Turkish citizens have a significantly higher average living area $(118.43 \pm 35.10)$ than refugees $(t=-6.281$, $\mathrm{p}<0.001)$.

The living area and the total number of contacts exhibited a statistically significant positive Spearman's correlation $\left(\mathrm{r}^{\mathrm{S}}=0.292\right.$, $\mathrm{p}<0.001)$.

\section{DISCUSSION}

In our study, tuberculosis is seen to infect a higher number of people through a situation caused by non-blood-related people living together (communal living style) and refugees brought to the country due to a war. Turkish citizens were more likely to live in a nuclear family type than refugees, who tended to exhibit a communal living situation.

A total of $98(50.5 \%)$ participants in this study were refugees, and $72(37.1 \%)$ lived in a nuclear family. It was determined that $57(58.2 \%)$ of the refugees have a communal living situation, where $47(49.0 \%)$ of the Turkish citizens lived with their nuclear families. Using scanning methods, the number of contacts among the refugees was determined to be 549 , with a total living area of $7,740 \mathrm{~m}^{2}$ and an average living area per person of $14.09 \mathrm{~m}^{2}$. With the Turkish citizens, the number of scanned contacts was found to be 487 , with a total living area of $11,370 \mathrm{~m}^{2}$ and an average living area per person of $23.34 \mathrm{~m}^{2}$. The number of contacts starting on preventive treatment was 247 among refugees and 138 among Turkish citizens. In this study, statistical significance was found between different living styles, namely nuclear families and communal living. According to the total number of contacts, statistical significance was also detected among nuclear family, extended family and communal living styles. A statistically significant relationship was found in accordance with nationality type, as the mean living area per person among Turkish citizens was much higher than that of refugees. In addition, a statistically significant positive correlation was also observed between living area and the total number of contacts.

While accomplishments have been achieved regarding wars and their effect on the spread of tuberculosis $(1,3,4,9,14)$, threats to social life still exist (15). Wars are an obstacle for the eradication of tuberculosis, which has been a threat to human lives for thousands of years $(3,4)$.

Family members who have contact with the patient risk infecting other people as well as their co-workers (16). Collective living areas, such as schools, dormitories, barracks, and prisons $(1,17)$, as well as communal family living situations are similar in that people without any blood relation live together. In tuberculosis guidelines, refugee patients have been shown to be a high-risk group in terms of contacted examinations and procedures such as diagnosis and treatment $(1,9)$. The outcomes of this study support the guidelines in terms of the average living space per person and the communal living style of many refugees. Our study shows that the work environment of the refugees should also be taken into account along with their home environment. Balbay et al. looked into the living conditions of tuberculosis patients, finding that $80.6 \%$ of patients shared the same home with one to four other people, and $68.9 \%$ of patients lived in properties with two or three rooms (17). In the present study, refugees were seen to live with many more people; the people sharing the living area with the refugees being non-blood related (communal living) is also new information for the literature.

In some studies, although tuberculin skin tests (TST) and chest radiography screenings are suggested when needed (18), the analysis of the cost-effectiveness of screening programmes had concluded that current radiographic screening programmes have a minimal effect and are not low-cost (19). In our study, patients with tuberculosis and their contacts were scanned and proceeded with their treatment. Nevertheless, a scanning procedure cannot be executed in typical scenarios due to number of refugees on the first arrival, which can reach millions. Some studies have suggested anonymous scanning systems with regard to security concerns $(20,21)$. In the present study, latent tuberculosis infection scanning was realised with tuberculin. For both Turkish citizens and refugees, the number of the contact examinations per patient was seen to have increased (1). In a study done in tent camps for refugees, similar results were established in terms of tuberculosis patients and contact persons between refugees and Turkish citizens (22). As the degree of vaccination is above $95 \%$ in temporary shelters (23), health services in refugee shelters could be considered sufficient. However, these services are more limited for refugees living out of camps (24). As for the present study, communal living situations were certainly seen to increase the number of contacted individuals, but this rise was mostly caused by out-of-camp refugees rather than those living in tent cities. Refugees tend to live in tent camps and also have accessible health services, despite living in small, limited spaces. Our results display that the number of contacts is higher among refugees in communal living areas outside of tent camps.

Approximately 244 million immigrants lived throughout the world in 2015, one-third of whom were documented (25). In 2014, 19.5 million refugees were reported worldwide. In 2019, 3.6 million refugees were living safely in Turkey, many of whom 
were from Syria (26). However, undocumented immigrants and refugees are still a crucial problem, and serious obstacles are often in the way of receiving needed health services $(1,9,27)$. In our study, undocumented tuberculosis patients and contacts were reported to the relevant departments for registration certificates and given proper health examinations.

\section{CONCLUSION}

Tuberculosis patients were found to infect more people in war-related life conditions. This is caused by people who are not blood relatives living together, otherwise known as communal living. This is new information for the literature. Communal living should be taken into account in the contact examination of refugees with tuberculosis, and the obstacles to reach health services for refugees living outside of camps should be examined.

\section{Acknowledgements}

We thank medical student Melike Buyukakincak for the translation of the report.

\section{Authors' Contribution}

Conception: ŞK, RC, ZHAS; Design: ŞK, RC, ZHAS; Supervision: ŞK, RC, ZHAS; Funding: ŞK; Materials: ŞK, ZHAS; Data collection and processing: ŞK, RC; Analysis and interpretation: ŞK, RC, ZHAS; Literature review: ŞK, RC, ZHAS; Writer: ŞK, RC, ZHAS; Critical review: ŞK, RC, ZHAS

\section{REFERENCES}

1. Kara F, editor. Tuberculosis diagnosis and treatment guide. 2nd ed. Ankara: Ministry of Health; 2019. (In Turkish.)

2. War, migration and health: what should physicians do? Symposium [Internet]. 2016 [cited 2019 Aug 9]. Available from: http://www.ttb.org tr/halk sagligi/2016/02/28/savas-goc-ve-saglik-hekimler-ne-yapmalisempozyumu/. (In Turkish.)

3. World Health Organization. The Global plan to stop TB: 2011-2015. Geneva: WHO; 2010

4. World Health Organization. Global tuberculosis control: WHO report 2011. Geneva: WHO; 2011.

5. Office of the United Nations High Commissioner for Refugees. Convention and protocol relating to the status of refugees [Internet]. Geneva: UNHCR; 2010 [cited 2019 Aug 9]. Available from: https://www.unhcr. org/protection/basic/3b66c2aa10/convention-protocol-relating-statusrefugees.html.

6. Eyce B. Turkish family structure from history to present. J Selcuk Univ Soc Sci Vocat Sch. 2000;3(4):223-44. (In Turkish.)

7. Şahinkaya R. Family with psycho-social aspects. Ankara: Kardeş Printing House; 1975. (In Turkish.)

8. Serim T. Family structure in Turkey. Ankara: Hacettepe University Publications; 1972. (In Turkish.)
9. World Health Organization. Tuberculosis (TB): the End TB Strategy [Internet]. Geneva: WHO [cited 2019 Aug 9]. Available from: https:// www.who.int/tb/strategy/en/.

10. Riley RL, Mills CC, O'Grady F, Sultan LU, Wittstadt F, Shivpuri DN. Infectiousness of air from a tuberculosis ward-ultraviolet irradiation of infected air: comparative infectiousness of different patients. Am Rev Respir Dis. 1962;85:511-25.

11. Behr MA, Warren SA, Salamon H, Hopewell PC, Ponce de Leon A, Daley CL, et al. Transmission of Mycobacterium tuberculosis from patients smear-negative for acid-fast bacilli. Lancet. 1999;353(9151):444-9.

12. Özkara Ş. Preventive treatment in tuberculosis. In: Özkara S, Kılıçaslan Z, editors. Tuberculosis. Istanbul: Thorax Books; 2010. p. 586-97. (In Turkish.)

13. Kısa B, Sarımurat N, Koyman S, Sayıcı Ş, Babalık A, Kılıçaslan Z. Tuberculosis screening and efficacy of prophylaxis in contacts of patients with pulmonary tuberculosis. Tuberk Toraks. 2016;64(1):27-33.

14. Wallace D, Wallace R. Problems with the WHO TB model. Math Biosci. 2019;313:71-80.

15. Turkish Medical Association. War is a public health problem [Internet]. Ankara: TMA; 2018 [cited 2019 Aug 10]. Available from: http://www. ttb.org.tr/125yc8b. (In Turkish.)

16. Jindani A, Aber VR, Edwards EA, Mitchison DA. The early bactericidal activity of drugs in patients with pulmonary tuberculosis. Am Rev Respir Dis. 1980;121(6):939-49.

17. Balbay O, Isikhan V, Annakkaya AN, Arbak P, Bilgin C, Bulut I, et al. Social and economical aspects of tuberculosis patients in Turkey: a study with 733 patients in 23 chest disease hospitals. Düzce Tip Fakültesi Dergisi. 2004;2:5-14. (In Turkish.)

18. Stauffer WM, Kamat D, Walker PF. Screening of international immigrants, refugees, and adoptees. Prim Care. 2002;29(4):879-905.

19. Dasgupta K, Schwartzman K, Marchand R, Tennenbaum TN, Brassard P, Menzies D. Comparison of cost-effectiveness of tuberculosis screening of close contacts and foreign-born populations. Am J Respir Crit Care Med. 2000;162(6):2079-86.

20. Kim DY, Ridzon R, Giles B, Mireles T, Garrity K, Hathcock AL, et al. A no-name tuberculosis tracking system. Am J Public Health. 2003;93(10):1637-9.

21. Heldal E, Kuyvenhoven JV, Wares F, Migliori GB, Ditiu L, Fernandez de la Hoz K, et al. Diagnosis and treatment of tuberculosis in undocumented migrants in low- or intermediate-incidence countries. Int J Tuberc Lung Dis. 2008;12(8):878-88.

22. Kurtuluş Ş, Sak ZHA, Can R. Chest diseases in refugees living in a tent camp and in Turkish citizens living in the District: Ceylanpinar experience. Turk Thorac J. 2018;19(3):117-21.

23. Ergönül Ö, Tülek N, Kayı I, Irmak H, Erdem O, Dara M. Profiling infectious diseases in Turkey after the influx of 3.5 million Syrian refugees. Clin Microbiol Infect. 2020;26(3):307-12.

24. Tayfur I, Günaydin M, Suner S. Healthcare service access and utilization among Syrian refugees in Turkey. Ann Glob Health. 2019;85(1):42. doi: 10.5334/aogh.2353.

25. United Nations, Department of Economic and Social Affairs, Population Division. International Migration Report 2015: highlights. Geneva: United Nations; 2016.

26. Zimmerman C, Kiss L, Hossain M. Migration and health: a frame work for 21 st century policy-making. PLoS Med. 2011;8(5):e1001034. doi: 10.1371/journal.pmed.1001034.

27. Castelli F, Sulis G. Migration and infectious diseases. Clin Microbiol Infect. 2017;23(5):283-9. 